\title{
The Effects of Leadership Style on Employees' Job Satisfaction and Organizational Citizenship Behavior Across Hierarchical Levels
}

\author{
Rezky Ariany Aras ${ }^{1, *}$, Muhammad Jufri ${ }^{2}$ \\ ${ }^{1}$ Hasanuddin University, Indonesia \\ ${ }^{2}$ Makassar State University, Indonesia \\ *Corresponding author. Email: rezkyariany@unhas.ac.id
}

\begin{abstract}
Research has shown that leaders play a crucial role in driving a team's performance. In performing this role, leaders use different styles of leadership. Some leaders combine different leadership styles, such as directive and participative, and adjust them according to their situation. Leaders exist at varying hierarchies within the organizational structures, from lower-level supervisors to the top management level. As the new organizational paradigm emerges, decentralization and empowerment of lower-level leaders become essential in driving the organization's success. At the same time, leadership development at different hierarchies improves as information sharing, empowerment, and teams' development becomes more common. This study aims to understand different effective leadership styles in organizational leadership hierarchy, specifically job satisfaction and Organizational Citizenship Behavior (OCB). This research adopts the correlational design with a cross-sectional survey design. The model uses a variance analysis for data analysis. The study found that there is no variance in leadership style in an organizational hierarchy. This research shows that the transformational style is most effective in driving OCB and job satisfaction.
\end{abstract}

Keywords: Leadership style, job satisfaction, $O C B$

\section{INTRODUCTION}

Leader is a person who is considered to be more than the others and elected or assigned as the one in charge to manage other people. Researchers have found that a leader will significantly affect an organization's productivity, performance, and improvement [1,2,3]. Moreover, Raja and Palanichamy [4] stated that leadership is essential in transformation initiation and implementation in an organization.

Both practitioners and researchers suggest that previous leadership paradigm comparisons such as directive compared to participative leadership, consideration leadership to initiating structure type, autocratic to democratic, and task-oriented to relationship-oriented shall be expanded if a leader wants to positively affect individuals, teams, and organization [4].

Model framework for transactional/ transformational leadership had been developed by Bass [5]. The framework was developed in a bigger organizational context and successfully applied to study leadership in higher-level management [6]. Transformational and transactional leadership styles are defined as relationship and task-oriented leadership [7] and directive and participative leadership [8]. Transactional leadership mainly motivates individuals through reward contingency and management's active role in employee performance. The transactional leader defines purpose, expresses his/her expectations for the organization members and how they will be rewarded for their effort and commitment, and gives constructive feedback to maintain members' work performance $[9,10]$.

On one side, transformational leadership is a type of leader that is charismatic, inspirational, intellectually stimulating, and provides individual attention [11]. This type of leader helps members deal with their personal interests for the sake of the organization's bigger visions. They believe in their members, and they are motivated by a set of values such as loyalty, faith, individual attention, and positive things that affect organizational commitment. 
The organization chart consists of several levels of leadership; Ansari and Naeem [12] stated that it is wrong to think that lower and middle-level management have a less significant impact on an organization's growth and development. New organizational paradigms such as decentralization and lower management development and development of leaders on all hierarchy levels contribute to improving organizational success. Information sharing, people development, and the widespread use of teams also contribute to leader development on different hierarchy levels [6].

Several researchers have studied manager leadership styles on hierarchy levels in an organization. Ohio State Leadership study emphasizes two factors, consideration and the initiation of structure [12]. Likert's (1959) motivational approach and McGregor's [13] $\mathrm{X}$ and $\mathrm{Y}$ theory implicitly encourage more consideration of all leadership behavior. Based on those studies, the following thoughts were empirically tested by Fiedler, thus developing contingency theory [7]. Blake and Mouton [14], in managerial grid theory, recommend that leaders shall consider their ability on task (initiating) and people with behavioral orientation (considerations). Hersey and Blanchard on life cycle theory correlate members' maturity with ideal leader's behavior - telling, selling, participating, and delegating [15].

Until 1978, the focus was on lower-level management for smaller groups, while more amorphic executive leadership for inducting larger-scale transformation was neglected. Those affect the increasing numbers of researches that emphasized more transactional leadership types until, in the end, the transformational leadership type was introduced. Transformational leadership emphasizes vision and organizational changes. The rise of transformational leadership in the 1980s brought the idea that the primary function of leadership is to produce adaptive or useful changes [12].

On leadership type implementation, Bass [16] further stated that most managers use both directive and participative leadership types for various levels, depending on the situation. This research aims to determine effective leadership type towards job satisfaction and employee's OCB on different leadership hierarchies.

\section{METHOD}

Data collection was performed using a selfadministered questionnaire. The subjects on this study are staff and supervisors up to three to four organizational hierarchy levels on PT. Toyota Kalla, PT. Prodia, and R8 Mart at Makassar. This study's data collection technique used leadership, job satisfaction, and OCB scale. All three scales used were the interpretation of a standardized scale with tested validity and reliability.

OCB scale used was The Organizational Citizenship Behavior Checklist adaptation scale developed by Fox and Spector to measure the frequency of OCB on employees [17]. Job satisfaction scale used was The Short-Form MSQ adaptation scale developed by Weiss, Dawis, Lofquist, and England in 1966 [18] to measure employees' job satisfaction levels. The Short-Form MSQ was an inventory consisting of 20 items. The Short-Form MSQ's psychometric results were reliability coefficient ranged between 0.87-0.92. Leadership scale used was Multifactor Leadership Questionnaire (MLQ) adaptation scale developed by Bass and Avolio in 1995. The psychometric result of the MLQ was the reliability of 0.96 and 0.89 .

The analysis model used was variants analysis; Cardinal and Aitken [19] stated that variants analysis (ANOVA) is similar to the regression used in studying and investigating the relationship model between dependent and independent variables.

\section{RESULT}

Research data descriptions for empiric and hypothetic means are as shown in Table 1. Based on the data, we can tell that the respondents in this study have above-average job satisfaction levels. That was caused by a higher empiric mean compared to the hypothetic mean. However, on the other hand, the OCB behaviors were below average. The subjects in this study were employees and employees and supervisors in several private companies.

The relationship between OCB and job satisfaction on the subjects may also be known through their demographic distribution. The comparison of OCB and job satisfaction based on job position is shown in Table 2.

Based on Table 2, it is known that there is a difference between OCB and employees; job satisfaction is based on the job position. Employees on 
the supervisor level have a higher mean level of OCB and job satisfaction than employees on the staff level.

A hypothesis test was done using variants analysis. Cardinal and Aitken [19] stated that variants analysis (ANOVA) is similar to the regression used in studying and investigating the relationship model between dependent and independent variables. The hypothesis in this study is that there is a difference in effective leadership type for lower-level and top-level managers in affecting OCB and employees' job satisfaction. In that case, transactional leadership type is more effective on the low-level manager, while transformational leadership is more effective on toplevel managers. The hypothesis was tested using Univariate Analysis of Variance. The analysis showed that $\mathrm{F}$ manager level $*$ leadership type $=0.005$ with $\mathrm{p}$ - value $=0,943$. It shows that there is no interaction between manager level and leadership type in terms of employees' OCB behavior. The same result is shown in job satisfaction where $\mathrm{F}$ manager level * leadership type $=0.006$ with $\mathrm{p}$-value $=0.939$.

Furthermore, it is shown that leadership type influences employees' OCB regardless of management level. The F value is $37.111(\mathrm{p}<0.01)$ based on the statistics. This study also shows that leadership affects employees' job satisfaction, with an F value of 19.009 $(p<0.01)$. For both OCB and job satisfaction, it is shown that the transformational leadership type is more effective than the transactional type, while the transactional leadership type is more effective than the laissez-faire leadership type.

Table 1. Descriptive statistics

\begin{tabular}{|c|c|c|c|c|c|c|}
\hline Data & Variable & $\bar{N}$ & Mean & $S D$ & Min & $\overline{\operatorname{Max}}$ \\
\hline \multirow{2}{*}{ Empiric } & OCB Behavior & $\begin{array}{l}7 \\
2\end{array}$ & 101,611 & 21,974 & 49 & 141 \\
\hline & Job satisfaction & $\begin{array}{l}7 \\
2 \\
\end{array}$ & 73,389 & 9,294 & 36 & 91 \\
\hline \multirow{2}{*}{ Hypothetic } & OCB Behavior & $\begin{array}{l}7 \\
2 \\
\end{array}$ & 108 & 24 & 36 & 180 \\
\hline & Job satisfaction & $\begin{array}{l}7 \\
2\end{array}$ & 60 & 13,333 & 20 & 100 \\
\hline
\end{tabular}

Table 2. The difference between OCB and employees' job satisfaction in terms of job position

\begin{tabular}{cllcccc} 
& & $\mathrm{N}$ & Mean & $\mathrm{F}$ & Sig. \\
\hline OCB & 1) & Supervisor & 30 & 112,133 & \multirow{2}{*}{0,000} \\
& 2) & Staff & 42 & 94,095 & \multirow{2}{*}{0.942} & \multirow{2}{*}{0,001} \\
\hline Job & $1)$ & Supervisor & 30 & 77,567 & \multirow{2}{*}{12,002} & \\
satisfaction & 2) & Staff & 42 & 70,405 & & \\
\hline
\end{tabular}

\section{DISCUSSION}

This research aims to understand the effective leadership type on management hierarchy in an organization structure. Ansari and Naeem stated that there are significant leadership type differences between senior and junior level managers [12]. Their research shows that transformational leadership type is applied the most on senior manager level, while middle managers tend to use transactional and autocratic types, and junior level managers use autocratic type. Furthermore, Ansari and Naeem stated that the differences were caused by the difference in task and responsibility from junior to senior levels [12]. However, this research does not show the difference between leadership types and managerial levels on an organization's hierarchy. Both supervisors and managers may have two or even three leadership styles: transformational, transactional, and laissezfaire. Mullins also explains that leaders may have various approaches to leading and managing their organization and subordinates regardless of their position as junior or senior level managers [20]. Quinn further found that a more effective manager shall have the ability to use different approaches to fulfilling his role as a leader [21].

This research also shows that the leadership type deemed to have the most effective influence on OCB and job satisfaction level is the transformational type, followed by transactional and laissez-faire type. This is in line with Tyssen, Waid, \& Heidenreich's research that shows transformational and transactional types' influence on subordinates' work commitment [2]. In 
this case, the transformational type was proven more effective than the transactional type. Moreover, Marmaya, Torsiman, and Balakrishnan found that transformational and transactional leadership positively influences employees' work commitment. In that case, Malaysian employees were affected more by transformational type [22]. The transformational type was deemed essential to ensure buy-in by the employees. Research result by Wu \& Shiu [23] also states that the Laissez-Faire type is different from the transformational and transactional type, where leaders that adopt laissez-faire style control less and let their subordinates work freely without direct supervision. Laissez-Faire type delegates decision-making to the group and approve their resolution.

Transformational leadership can identify the subordinate's needs and give them support and guidance to work together towards the organization's goal. That helps in improving the employees' commitment level [24]. Other findings also show the significant relationship between transactional and organizational commitment [25]. This research also shows how transformational is more effective than transactional, with $\mathrm{p}<0.001$. This finding is consistent with the previous research done by Cemaloglu, Segzin, and Kiling [26]. Another possible explanation will be that commonly well-educated office staff feels that they may gain more from the transformational leadership style.

This research has contributed empirical evidence regarding the effect of leadership type on OCB and job satisfaction level. However, this research is a crosssectional study, thus limiting the conclusion regarding the relationship of all three variables. A longitudinal design is needed to validate this study from time to time to understand the causal relationship. The other limitation is that all the data were self-report surveys. Thus, the data tends to be more subjective. Using another method may be more interesting for future research on this subject to avoid this subjectivity issue, especially when measuring how the respondents play their roles as leaders in the leadership type scale. Thirdly, the subjects of this research are still limited; further external validity check is needed to measure these findings on different job populations such as factory and field workers.

\section{CONCLUSION}

Based on the above results and elaborations, it may be concluded that the research hypothesis is rejected. There is no significant difference between leadership hierarchy and effective leadership type towards OCB and job satisfaction level. However, the data shows that the transformational type is the most effective for OCB and job satisfaction level regardless of the hierarchy.

\section{REFERENCES}

[1] Reid, W., \& Karambayya, R., Impact of dual executive leadership dynamics in creative organizations, Human Relations, 2009, 62(7), pp. 1073-1112. DOI: $10.1177 / 0018726709335539$

[2] Tyssen, A.K., Wald, A., \& Heidenreich, S., Leadership in the context of temporary organization: A study on the effects of transactional and transformational leadership on followers' commitment in projects. Journal of Leadership \& Organizational Study, 2014, 21(4), pp. 367-393. DOI: $10.1177 / 1548051813502086$

[3] Carter, S.M., \& Greer, C. R., Strategic leadership: Values, styles, and organizational performance. Journal of Leadership \& Organizational Studies, 2016, 20(4), pp. 375393. DOI: $10.1177 / 1548051812471724$

[4] Raja, A.S., \& Palanichamy, P., Leadership style and its impact on organizational commitment, Asia-Pacific Business Review, 2011, 7(3), pp. 167-175.

[5] Riggio, R. E., Introduction to industrial/ organization psychology, Person Prentice Hall, 2003.

[6] Lowe, K. B., Kroeck, K.G., Sivasubramaniam N., Effective correlation of transformational and transactional leadership: A meta-analytical review, Leadership Quarterly, 1996, 7(3), pp. $385-425$.

[7] Fiedler, F., A Theory of Leadership Effectiveness, McGraw-Hill, 1967.

[8] Heller, F.A., Yukl, G., Participation, managerial decision-making, and situational variables, Organizational Behavior and Human Performance, 1969, 4, pp. 227-241.

[9] Bass, B. M., Avolio, B. J., Transformational leadership: A response to critiques. Dalam M. M. Chemers \& R. Ayman (Eds.). Leadership Theory and Research: Perspectives and Directions, Academic Press, 1993.

[10] Howell, J. M., Avolio, B.J., Transformational leadership, transactional leadership, locus of control, and support for innovation: Key predictors of consolidated business-unit 
performance, Journal of Applied Psychology, 1993, 78, pp. 891-902.

[11] Avolio B. J., Bass, B.M., Jung, D.I., Reexamining the components of transformational and transactional leadership using the multifactor leadership questionnaire, Journal of Occupational and Organizational Psychology, 1999, 72, pp. 441-462.

[12] Ansari, A. H., \& Naeem, F., Leadership styles across hierarchical levels: A case study on Indian automobile industry, Asia Pacific Business Review, 2010, 6(3), pp. 115-123. DOI: $10.1177 / 097324701000600310$.

[13] McGregor, D. M., The Human Side of Enterprise, McGraw-Hill, 1960.

[14] Blake, R., \& Mouton, J., The managerial grid: the key to leadership excellence, Gulf Publishing Company, 1964.

[15] Hersey, P., \& Blanchard, K.H., (1969). Life cycle theory of leadership, Training \& Development Journal, 1969, 23(5), pp. 26-34.

[16] Clark, R.A.m Hartline, M.D., \& Jones, K.C., The effects of leadership style on hotel employees' commitment to service quality, Cornell University, 2009, 50(2), pp. 209-231. DOI: $10.1177 / 1938965508315371$

[17] Fox, S., Spector, P. E., Goh, A., Bruursema, K., \& Kessler, S. R., The deviant citizen: Clarifying the measurement of organizational citizenship behavior and its relation to counterproductive work behavior, Loyola University Chicago, 2009.

[18] Weiss, D. J., Dawis, R. W., \& Lofquist, L. H., (1966). Instrumentation for the theory of work adjustment, Minnesota Studies in Vocational Rehabilitation, 1966, 21, 85.

[19] Cardinal, R.N., \& Aitken, M.R.F., Anova for the behavioral Sciences Researcher, Psychology Press, 2005.

[20] Mullins, L. J., Management \& Organizational Behavior, Pearson Education Limited, 2010.

[21] Quinn, R., Summary of the Quinn/ Rohrbaugh Model for analyzing organizational effectiveness and leadership roles, 2016. Retrieved from: http://www.valuebasedmanagement.net/metho ds quinn competing values framework.html

[22] Marmaya, N. H., Hitman, M., Torsiman, N. N. \& Balakrishnan, B., Employee's perception of Malaysian managers leadership styles and organizational commitment.Africa, Journal of Business Management, 2011, 5(5), pp. 15841588. DOI: $10.5897 /$ AJBM10.090
[23] Wu, F. Y. \& Shiu, C., The Relationship between leadership styles and foreign English teachers job satisfaction in adult English cram schools: Evidences in Taiwan, The Journal of American Academy of Business, 2009, 14(2).

[24] Ahmad, A., Majid, A. H. A., \& Zin, M. L. M., The measurement of the effectiveness of leadership styles for organizational commitment in Pakistan, Asian Social Science, 2015, 11(25), pp. 135-143.

[25] Madanipour, M., The influence of attachment style on the relationship between leadership, organizational commitment, and organizational citizenship behavior, Alliant International University, 2013.

[26] Cemaloglu, N., Sezgin, F., \& Kiling, A. C., Examining the relationships between school principals transformational and transactional leadership styles and teachers organizational commitment, The Online Journal of New Horizons in Education, 2012, 2(2), pp. 53-64. 